\title{
JUNO CAELESTIS AND SEPTIMIUS SEVERUS
}

\begin{abstract}
Summary: The Historia Augusta mentions some oracles of Juno Caelestis, the Carthaginian goddess who uttered them shortly before the reigns of Pertinax and Severus. This Juno and her prophecies were imporant to the author of the Historia Augusta mainly because they were concerned with the forthcoming death of Commodus and the coming of Pertinax and Severus.
\end{abstract}

Key words: prophecy, Severan Age, Juno Caelestis, Carthage

An ancient goddess by the name of Juno Caelestis of Carthage was worshipped in the Roman period. The Roman colony Julia Carthago was inhabited by Italian colonists, who were settled there by Caesar and Augustus. An early attempt to establish a colony was made by Caius Gracchus, but his planned colonia Junonia Carthago failed shortly before his death. The name "Junonia" is an evident statement of the role of this goddess at Carthage. She was also a prophetic goddess, who caused some problems to Pertinax, the governor of Africa shortly before (189-190 AD $\left.{ }^{1}\right)$ the death of Commodus. A new study on her prophecies and their political involvement in this period could prove helpful to understand a related problem, namely that of the relationship between Juno Caelestis and the Severan dynasty.

The Historia Augusta reports that Pertinax did not duly repress the mob which ensued from some prophetic utterances of Caelestis:

Dein pro consule Africae factus est. In quo proconsulatu multas seditiones perpessus dicitur vaticinationibus tearumt, quae templo Caelestis emergunt. (SHA, Pertinax 4)

\footnotetext{
${ }^{1}$ On the date, see ThOMAsson 1960.
} 
Then his proconsulship of Africa was established. During this proconsulship, it is said, he tolerated many rebellions fed by some prophecies which issued from the temple of Caelestis.

The text and its meaning are controversial, and no convincing correction has been proposed for earum, hitherto. ${ }^{2}$ However, the meaning is quite clear, except for the expession perpessus vaticinationibus, which could mean either "he tolerated the mob produced by the prophecies", or "he tolerated the mob thanks to the prophecies". 3

Picard explained the mob as a possible consequence of some reforms in the cult of Caelestis, which were bitterly contrasted by an allegedly old fashioned Punic clergy. Moreover, according to this author, Pertinax, Laetus, the Guard Prefect, and their friends used these mobs to justify the missing food supplies from Africa to Rome. But this is far from ascertained.

Several scholars condemn as fictitious all the stories concerning Caelestis in the Historia Augusta. ${ }^{4}$ The axiom that a story must be fictitious if reported by the Historia Augusta can not always be acceptable. In this case only a detail speaks against the historicity. In another passage, concerning Macrinus, ${ }^{5}$ another oracle by Caelestis is mentioned, according to which a Roman governor, under Antoninus Pius, inquired about his own governorship in Africa and about the emperors, and the answer was simply a series of eight names of Antoninus.

de ipso quae in annales relata sint proferam: vates Caelestis apud Carthaginem, quae dea repleta solet vera canere, sub Antonino Pio, cum sciscitante proconsule de statu, ut solebat, publico et de suo imperio futura praediceret, ubi ad principes ventum est, clara voce numerari iussit quotiens diceret Antoninum, tuncque adtonitis omnibus Antonini nomen octavo edidit. sed credentibus cunctis quod octo annis Antoninus Pius imperaturus esset, et ille transcendit hunc annorum numerum, et constitit apud credentes vel tunc vel postea per vatem aliud designatum. denique adnumeratis omnibus qui Antonini appellati sunt is Antoninorum numerus invenitur. enimvero Pius primus, Marcus secundus, Verus tertius, Commodus quartus, quintus Caracallus, sextus Geta, septimus Diadumenus, octavus Heliogabalus Antonini fuere (SHA, Opilius Macrinus 3. 1-4)

\footnotetext{
${ }^{2}$ PICARD 1959, corrected earum into canum, i.e. the Canes, who were some Phoenician priests and supposedly also Carthaginian members of the priestly staff of Caelestis' temple. Other corrections have been: carminum (Peter, ed. Teubner, 1884), sortium earum (NovAK 1896), and certum (Hohl, ed. Teubner, 1927).

${ }^{3}$ See PiCARD 1959, 45-46. Contra: BARNes 1970, 98; LANCELlotTi 2010, 47.

${ }^{4}$ SYME 1968, 139-140; BARNES 1970, 96-101.

${ }^{5}$ SHA, Macrinus 3. 1-4.
} 
Concerning Diadumen(ian)us I will relate what has been recorded in books of history. The priestess of Caelestis at Carthage was wont, when inspired by the goddess, to predict the truth. Now once, in the reign of Antoninus Pius, she was foretelling the future to the proconsul, who, according to custom, was consulting about the public welfare as well as his own hopes of power, and when she came to the emperors she bade him in a loud voice count the number of times she said Antoninus. Then, to the amazement of all, she uttered the name Antoninus eight times. All interpreted this to mean that Antoninus Pius would reign for eight years, but he exceeded this number and those who had faith in the priestess, either then or later, felt sure that her words had some different meaning. And in fact, if all who bore the name Antoninus be counted, this will be found to be their number. For Pius first, Marcus second, Verus third, Commodus fourth, Caracalla fifth, Geta sixth, Diadumenianus seventh, Elagabalus eighth all bore the name Antoninus.

The meaning of the oracle became clear only under Macrinus, whose son was the seventh Antoninus, and whose successor was the eighth and latest Antoninus, i.e. Heliogabalus. The falseness of this account resides in the statement that this kind of inquiry was usual (ut solebat), whereas in fact it was strictly forbidden, especially if it related to the emperors and the empire. This detail determined the condemnation of the prophecies by Caelestis mentioned in the Historia Augusta. More plausibly Giuseppe Zecchini ${ }^{6}$ maintains that these prophecies were not invented by the Historia Augusta, but reported by some more ancient authors, and that earlier Marius Maximus mentioned the oracle of the eight Antonini. Caelestis was apparently more concerned with prophecy than with Latin Juno, and we do not know whether this depended on ancient Punic traditions or on a local trasformation, possibly due to other African towns in which Juno Caelestis was also worshipped, but with some local African features.

The focus of the above-mentioned prophecy was not on the Antonine age, but on the period of Macrinus and Heliogabalus, and the aim of the Historia Augusta was not that of entertaining with fictitious stories, but that of convincing the readers that the prophecies of pagan gods on the destiny of the Empire were reliable and true. The same aim inspired also Ammianus Marcellinus and other pagan authors of the Late Antiquity, and the controversy on pagan prophecies was one of the reasons why the emperor Constantius II in 357 forbade all the prophetic inquiries: Sileat omnibus perpetuo divinandi curiositas ("let curiosity about divining be unspoken by all in perpetuity").

The authors of the Historia Augusta could draw abundant information from the treasury of historical works from the Severan period. Septimius Severus himself reported in a diary all the prodigies, signs, prophecies and dreams which forecast his imperial power, and entrusted Cassius Dio with it and encouraged him to write a book

\footnotetext{
${ }^{6}$ ZECCHINI 1983, 150-167.

${ }^{7}$ Cod. Theod. 9. 16. 4.
} 
on this topic. ${ }^{8}$ The extant work of Cassius Dio frequently indulges in describing the numerous and meaningful predictions of the enthronement, of the power, and also of the end of this emperor. The Historia Augusta as well reports many prophecies and signs concerning the empire of the Severan emperors. In this period, astrology flourished and a room in the palace of Septimius was painted with the horoscope of this emperor himself, except some detail, which was kept in secrecy. ${ }^{9}$ He allegedly sought the marriage with Julia Domna because her horoscope destined her to marry a king. ${ }^{10}$ Bardaesanes, a Christian astrologer and writer of the Severan period, discussed the problem of the free will in a world ruled by astral determinism.

When Pertinax was in Carthago, Septimius Severus was governor of Sicily, in 189$190,{ }^{11}$ and here another episode of excessive tolerance of a crime occurred. The Historia Augusta, Severus 4.3 reports in fact the following story:

In Sicilia quasi de imperio vel vates vel Chaldaeos consuluisset, reus factus est. A praefect. praet., quibus audiendus datus fuerat, iam Commodo in odium veniente absolutus est calumniatore in crucem acto. ${ }^{12}$ (SHA, Severus 4. 3)

While he was in Sicily he was indicted for consulting with seers and astrologers about the imperial dignity, but, because Commodus was now beginning to be detested, he was acquitted by the prefects of the guard to whom he had been handed over for trial, while his accuser was crucified.

It is an ascertained historical fact that Commodus met a tough opposition in Rome during the years 190-192, and that the Guard Prefect Laetus was involved in a conspiracy which brought Commodus' life to an end. Pertinax was immediately chosen as the new emperor by the Senate, and Severus was in excellent terms with him. Severus consulted a Chaldean also on another occasion, in Africa, and he was told that he was destined to become an extremely powerful and prominent man. ${ }^{13}$

All these prophecies concerned the imperial power, and show that the Historia Augusta used one or more works of the Severan age which presented many prodigies, prophecies and other divine admonitions which forecast, on one hand, the empire of Pertinax and Severus, and on the other, Commodus' imminent fall.

It is thus highly probable that the prophecies by Caelestis also had something to do with the destiny of the Roman Empire. Pertinax tolerated the riots in Carthago and similarly the Prefects of the Pretorian Guard tolerated Severus' inquiry. In both these

\footnotetext{
${ }^{8}$ Cass. Dio 72. 23. 1-2.

${ }^{9}$ Cass. Dio 76. 11. 1.

${ }^{10}$ SHA, Severus 3.

${ }^{11}$ BiRLEY 1988, 77.

${ }^{12}$ SHA, Severus 4. 3.

${ }^{13}$ SHA, Severus 2.
} 
cases the hatred towards Commodus justified some indulgence concerning prophecies forecasting his imminent fall and the coming of a new ruler.

Another case is reported by the Historia Augusta, in which the usurper Celsus, at the time of Gallienus, was clad in the peplum of Caelestis. ${ }^{14}$ Here it is unimportant to establish the historicity or the falseness of this report, for it is enough to state the interest shown in the Historia Augusta in the political activity of Caelestis' temple. The Historia Augusta had at its disposal one or more works in which many prophecies and divine signs gave information on the destiny of the Empire.

The favor obtained by Caelestis under Severus and Caracalla is indisputable; in fact only these emperors struck coins with her image. ${ }^{15}$ Moreover, Julia Domna is identified with Caelestis in an inscription from Moguntiacum (Mainz). ${ }^{16}$ During the empire of Severus and Caracalla Caelestis was glorified in Africa and became one of the major glories of Carthago and maybe of other African cities as well. ${ }^{17}$ The Severan coins depicting Caelestis aimed at celebrating some liberality by Septimius Severus and his family in Carthago, ${ }^{18}$ but the emphasis was placed on the goddess more than on a specific building (a new aqueduct?) or a festival (the Pythicus agon?) which occasioned the coin issue. Saturnus was the most popular god in Roman Africa, but in spite of that Septimius and his dynasty apparently paid no particular attention to him. We have now at our disposal a possible reason for Caelestis' success, that is, her prophecies, which forecast the end of Commodus, and/or the coming of Pertinax and Severus, as well as the coming of some emperors called Antoninus, a prophecy which increased the prestige of Caelestis, because Severus' elder son Bassianus received the title of Caesar under the name of Marcus Aurelius Antoninus, and this was so controversial that a great war between Severus and Albinus ensued. The Historia Augusta ${ }^{19}$ reports that Severus inquired about his future successor and in a dream he saw that an Antoninus was to come after him. Because of this dream he called his son Marcus Aurelius Antoninus and styled himself as son of Marcus Aurelius and brother of Commodus. ${ }^{20}$

${ }^{14}$ SHA, XXXTyr, Celsus 29. 1.

${ }^{15}$ Coins struck under Severus, Julia Domna, and Caracalla show Caelestis on the reverse side, along with the inscription INDULGENTIA AUGG IN CARTH(aginem): RIC IV 1, Severus nos. 193, 266-267, 759-760, 763, 766; Caracalla: nos. 130a, 131a, 415, 418a, 471; GNECCHI 1910.

${ }^{16}$ CIL XIII 6671. The assumption of DOMASZEWSKI 1895, 74, according to which Caelestis became a very important goddess of the Roman Empire under the Severans has been challenged by MUNDLE 1961, 228-237, because a poetic epigraphic text from Britannia (CIL VII 759) celebrating Caelestis does not pertain to the Severan age and does not allude to Julia Domna. The criticism took the author of this article so far as to assume that Caelestis was meaningless to the Severan emperors (MUNDLE 1961, 237).

${ }^{17}$ See LANCELlOtTI 2010, 49, according to which Caelestis had "un ruolo importantissimo di contatto fra la provincia africana e gli imperatori di epoca severa", and this role was carried out in Africa more than in Rome.

${ }^{18}$ On the possible allusion of the indulgentia Augustorum to some event, see PERA 1979 and 1991; MundLE 1961, 234; LANCELLOTTI 2010, 48.

${ }^{19}$ SHA, Geta 1. 3-4.

${ }^{20}$ Cass. Dio 75. 7. 5. 
We conclude by stating that the Carthaginian Juno and her prophecies were imporant to the author of the Historia Augusta mainly because they were concerned with the story of the emperors, and particularly with the end of Commodus and the coming of Pertinax and Severus.

Attilio Mastrocinque

Dipartimento Filologia, Letteratura, Linguistica, Tempo, Spazio, Immagine, Società

Settore disciplinare Storia Romana

Università degli studi di Verona

Italia

\section{BIBLIOGRAPHY}

BARnES, T. D. 1970: The Goddess Caelestis in the "Historia Augusta". The Journal of Theological Studies, N.S. 21, pp. 96-101.

BIRLEY, A. R. 1988: The African Emperor. Septimius Severus. London.

Domaszewski, A. v. 1895: Die Religion des römischen Heeres. Trier

GNECCHI, F. 1910: I medaglioni romani. Milano, III 39, no. 7.

LAnCEllotti, M. G. 2010: Dea Caelestis: studi e materiali per la storia di una divinità dell'Africa romana. Pisa-Roma

Mundle, I. 1961: Dea Caelestis in der Religionspolitik des Septimius Severus und der Julia Domna. Historia 10, pp. 228-237.

NovaK 1896: Observationes in Scriptores Historiae Augustae. Prague

PERA, R. 1979: Probabili significati della scritta Indulgentia Augg in Carthaginem ed Indulgentia Augg in Italiam su alcune monete di Settimio Severo e Caracalla. Rivista Italiana di Numismatica 81, pp. 103-114.

PERA, R. 1991: I riferimenti all'Africa nelle emissioni monetali della Zecca di Roma. In Mastino, A. (a cura di): L'Africa romana. Atti del VIII Convegno di studio, Cagliari, 14-16 dicembre 1990. Cagliari, pp. 503-521.

PICARD, G.-Ch. 1959: Pertinax et les prophètes de Caelestis. Revue de l'histoire des religions 155 , pp. 41-62.

SYME, R. 1968: Ammianus and the Historia Augusta. Oxford

ThOMASson, B. E. 1960: Die Statthalter der römischen Provinzen Nordafrikas von Augustus bis Diocletianus. Bd. II. Lund, pp. 91-92.

ZeCCHINI, G. 1983: Il santuario della dea Caelestis e l'Historia Augusta. In Sordi, M. (ed.): Santuari e politica nel mondo antico [CISA IX]. Milano, pp. 150-167. 